\title{
The distribution and metabolism of nickel carbonyl in mice
}

\author{
AGNETA OSKARSSON AND H. TJÄLVE
}

From the Department of Toxicology, University of Uppsala, Box 573, S-751 23 Uppsala, Sweden

ABSTRACT The distribution of ${ }^{63} \mathrm{Ni}$ - and ${ }^{14} \mathrm{C}$-labelled nickel carbonyl was studied in mice by wholebody autoradiography and by liquid scintillation counting. Radioactivity from $\mathrm{Ni}\left({ }^{14} \mathrm{CO}\right)_{4}$ was found almost exclusively in the blood, probably because of the formation of ${ }^{14} \mathrm{CO}$-haemoglobin. After the administration of ${ }^{63} \mathrm{Ni}(\mathrm{CO})_{4}$ the highest level of ${ }^{63} \mathrm{Ni}$ was found in the lung. Other tissues accumulating a high amount of ${ }^{63} \mathrm{Ni}$ were the brain and spinal cord, the heart muscle, the diaphragm, brown fat, the adrenal cortex and the corpora lutea of the ovaries. A high level of ${ }^{63} \mathrm{Ni}$ was also present in the kidneys and the urinary bladder. Experiments designed to establish whether the nickel in the lung, the brain, the heart muscle and the blood was present in a non-ionised form, or as a cation, suggest that nickel is bound to these tissues in the cationic state $\left(\mathrm{Ni}^{++}\right)$.

Nickel carbonyl, $\left[\mathrm{Ni}(\mathrm{CO})_{4}\right]$, is an intermediate product in the Mond process for refining nickel; it is also used for vapour plating of nickel and as a catalyst in industrial organic synthesis (International Agency for Research on Cancer, 1976). It is an extremely toxic, highly volatile liquid, which has caused several cases of poisoning in industrial workers (Armit, 1907; Von Ludewigs and Thiess, 1970; Vuopala et al., 1970). The lung and the central nervous system have been found to be the principal target tissues of acute nickel carbonyl toxicity in man (Armit, 1907; Kincaid et al., 1953). Experimental nickel carbonyl poisoning in animals has shown that the most severe toxic reaction is localised in the lung, but injury may also be induced in tissues such as the brain and the adrenals (Armit, 1908; Barnes and Denz, 1951; Hackett and Sunderman, 1967).

Only a few studies on the fate of nickel carbonyl in experimental animals have been performed. It has been shown that, after the administration of nickel carbonyl, deposition of nickel occurs in the lung and in tissues such as the brain, the liver and the adrenals, and that a part of the administered dose of nickel is recovered in the urine (Armit, 1908; Barnes and Denz, 1951; Sunderman and Selin, 1968). While the early authors assumed that nickel carbonyl is rapidly dissociated in the lung and that nickel then is transported to other tissues, studies by Sunderman and co-workers (Sunderman and Selin, 1968; Sunderman et al., 1968; Kasprzak and
Sunderman, 1969) have indicated that unchanged nickel carbonyl is present in the blood for several hours and can pass across the pulmonary alveoli in either direction without decomposition. It was therefore proposed by Kasprzak and Sunderman (1969) that the nickel carbonyl which is not exhaled, undergoes a slow intracellular decomposition to $\mathrm{Ni}^{0}$ and $\mathrm{CO}$; the released $\mathrm{Ni}^{0}$ is then oxidised to $\mathrm{Ni}^{++}$, which may become bound to nucleic acids or proteins, or to albumin in the plasma and, ultimately, will be excreted in the urine; the released $\mathrm{CO}$ will become bound to haemoglobin and ultimately exhaled.

The present study was designed to obtain more detailed information on the fate of nickel carbonyl in the body. Thus, the distribution of radioactivity in the tissues of mice after the administration of ${ }^{63} \mathrm{Ni}$ - or ${ }^{14} \mathrm{C}$-labelled nickel carbonyl has been studied by whole-body autoradiography and by liquid scintillation counting. In addition, in an attempt to establish whether the nickel is bound to the tissues in a non-ionised form or as a cation, whole-body tissue sections of a mouse given ${ }^{63} \mathrm{Ni}(\mathrm{CO})_{4}$ have been incubated in solutions containing different cations. The ability of the cations to displace the ${ }^{63} \mathrm{Ni}$ from the tissues has then been determined by autoradiography, using densitometric measurements for the quantitative estimations.

\section{Materials and methods}

ANIMALS

Mice of the NMRI and the C57-Bl strains of both 326 
sexes, with body weights of $25 \mathrm{~g}$, were used. The animals were fed a conventional diet for laboratory rodents and were given tap water ad libitum.

\section{ISOTOPES}

Nickel carbonyl, ${ }^{63} \mathrm{Ni}$ - and ${ }^{14} \mathrm{C}$-labelled, specific activity $44.2 \mu \mathrm{Ci} / \mathrm{mg} \mathrm{Ni}$, was synthesised by $\mathrm{Dr}$ Karl Amlauer, Isotope Product Laboratories, Burbank, California.

\section{AUTORADIOGRAPHY}

The mice were either injected intravenously in a tail vein with $5 \mu \mathrm{Ci}{ }^{63} \mathrm{Ni}$ - or ${ }^{14} \mathrm{C}$-labelled nickel carbonyl $(4.52 \mathrm{mg} \mathrm{Ni} / \mathrm{kg}$ body weight, dissolved in $25 \mu \mathrm{l}$ absolute ethanol) or exposed by inhalation to the same amount of labelled nickel carbonyl [evaporated from $50 \mu \mathrm{l}$ ethanol:ether $(1: 1)]$. The exposure by inhalation was for $10 \mathrm{~min}$ in an inhalation apparatus, where the nose of the animal was exposed to the isotope in an air volume of $37 \mathrm{ml}$, corresponding to a concentration of $3.05 \mathrm{mg}$ $\mathrm{Ni} /$ litre. The animals were killed $5 \mathrm{~min}, 1 \mathrm{~h}, 4 \mathrm{~h}$, and $24 \mathrm{~h}$ after the administration of the nickel carbonyl, by immersion in gaseous carbon dioxide for $30 \mathrm{~s}$; they were subsequently frozen by immersion in liquid nitrogen. After $15 \mathrm{~min}$, the frozen animals were embedded in a mixture of carboxymethyl cellulose, cotton and water and frozen to a solid block in liquid nitrogen. The embedded mice were sectioned in a microtome on tape (20 $\mu \mathrm{m}$ thick sections) and autoradiography was performed with the dry tape sections (Ullberg, 1954). An attempt was also made to localise the volatile non-metabolised nickel carbonyl with lowtemperature autoradiography, using the procedure described by Östlund (1969). These experiments were unsuccessful, however, probably because of the high volatility of the substance.

THE ABILITY OF CATIONS TO DISPLACE

${ }^{63}$ NI FROM THE TISSUES

A series of tape sections ( $20 \mu \mathrm{m}$ thick) were taken from the mouse killed $5 \mathrm{~min}$ after inhalation of ${ }^{63} \mathrm{Ni}(\mathrm{CO}) 4$. After freeze-drying, the sections were incubated for $15 \mathrm{~min}$ in $100 \mathrm{ml}$ distilled water or distilled water supplemented with $\mathrm{HCl}$ or various cation-chloride salts. The $\mathrm{pH}$ of the incubation solutions was determined using a PHM62 standard $\mathrm{pH}$-meter with a glass electrode (Radiometer, Copenhagen, Denmark). The relative amount of radioactivity in the lung, the brain, the heart muscle and the blood after incubation was determined by autoradiography using densitometric measurements for the quantitative estimations. To make the quantification possible, standard isotope staircases (Berlin and Ullberg, 1963) containing ${ }^{63} \mathrm{Ni}$-radioactivity were exposed together with the tissue sections according to a procedure described previously (Oskarsson and Tjälve, 1979). The staircases comprised a series of polythenesupported gelatin layers containing different concentrations of ${ }^{63} \mathrm{Ni}$ in a geometric sequence, with the radioactive contents of adjacent steps related in the ratio $2: 1$, thus forming a gradually decreasing scale. The relative amount of radio activity in the tissues of the sections incubated in distilled water only, was assigned the relative value of $100 \%$, and the concentrations in the other sections were expressed as a percentage of this value.

LIQUID SCINTILLATION COUNTING

Three groups of mice, three mice per group, were injected intravenously with $1 \mu \mathrm{Ci}{ }^{63} \mathrm{Ni}(\mathrm{CO})_{4}$ $(0.90 \mathrm{mg} / \mathrm{kg}$ dissolved in $25 \mu \mathrm{l}$ absolute ethanol) per mouse. After respectively $1 \mathrm{~h}, 24 \mathrm{~h}$ and 4 days, one group of mice was anaesthetised with chloroform. Blood from the heart was collected in ACD solution $(0.48 \mathrm{~g}$ citric acid, $1.32 \mathrm{~g}$ sodium citrate and $1.47 \mathrm{~g}$ glucose in $100 \mathrm{ml}$ distilled water) and the animals were perfused with physiological saline. Tissue samples were removed, weighed and dissolved in $1 \mathrm{ml}$ Soluene $350{ }^{\circledR}$ (Packard) and $10 \mathrm{ml}$ of a scintillation fluid consisting of $4 \mathrm{~g}$ PPO (2,5-diphenyloxazole) and $0 \cdot 25$ gdimethyl-POPOP $\left[2,2^{1}-p\right.$-phenylenebis (4-methyl-5-phenyloxazole)] per litre toluene was added. The blood was centrifuged for 10 minutes at $2000 \mathrm{~g}$ and the radioactivity in the erythrocytes was determined after being dissolved in Soluene $10{ }^{\circledR}$ and isopropanol $(1: 1, \mathrm{v} / \mathrm{v})$. The sample was bleached by adding $0.5 \mathrm{ml}$ of $30 \%$ hydrogen peroxide; finally $0.5 \mathrm{M}$ hydrochloric acid and Insta-Gel ${ }^{\circledR}$ (Packard) $(1: 9, \mathrm{v} / \mathrm{v})$ was added as scintillation fluid. Insta-Gel ${ }^{\circledR}$ was also added to the plasma for determination of the radioactivity. The radioactivity of the samples was determined in a Packard model 2405 liquid scintillation counter. An external standard was used to correct for quenching.

\section{Results}

\section{AUTORADIOGR A PHY}

\section{${ }^{63} \mathrm{Ni}(\mathrm{CO})_{4}$ inhalation}

The tissues which attained the highest levels of radioactivity after inhalation of ${ }^{63} \mathrm{Ni}(\mathrm{CO})_{4}$ were the respiratory tissues, the brain and spinal cord, the heart muscle and the diaphragm, the adrenal cortex, brown fat and the kidney and urinary bladder (Figs 1a and $2 \mathrm{a}$ ). Detectable radioactivity was present in the blood at $5 \mathrm{~min}$, but had decreased to a low level at $1 \mathrm{~h}$ (Fig 1a). The distribution in various tissues at different time intervals after 

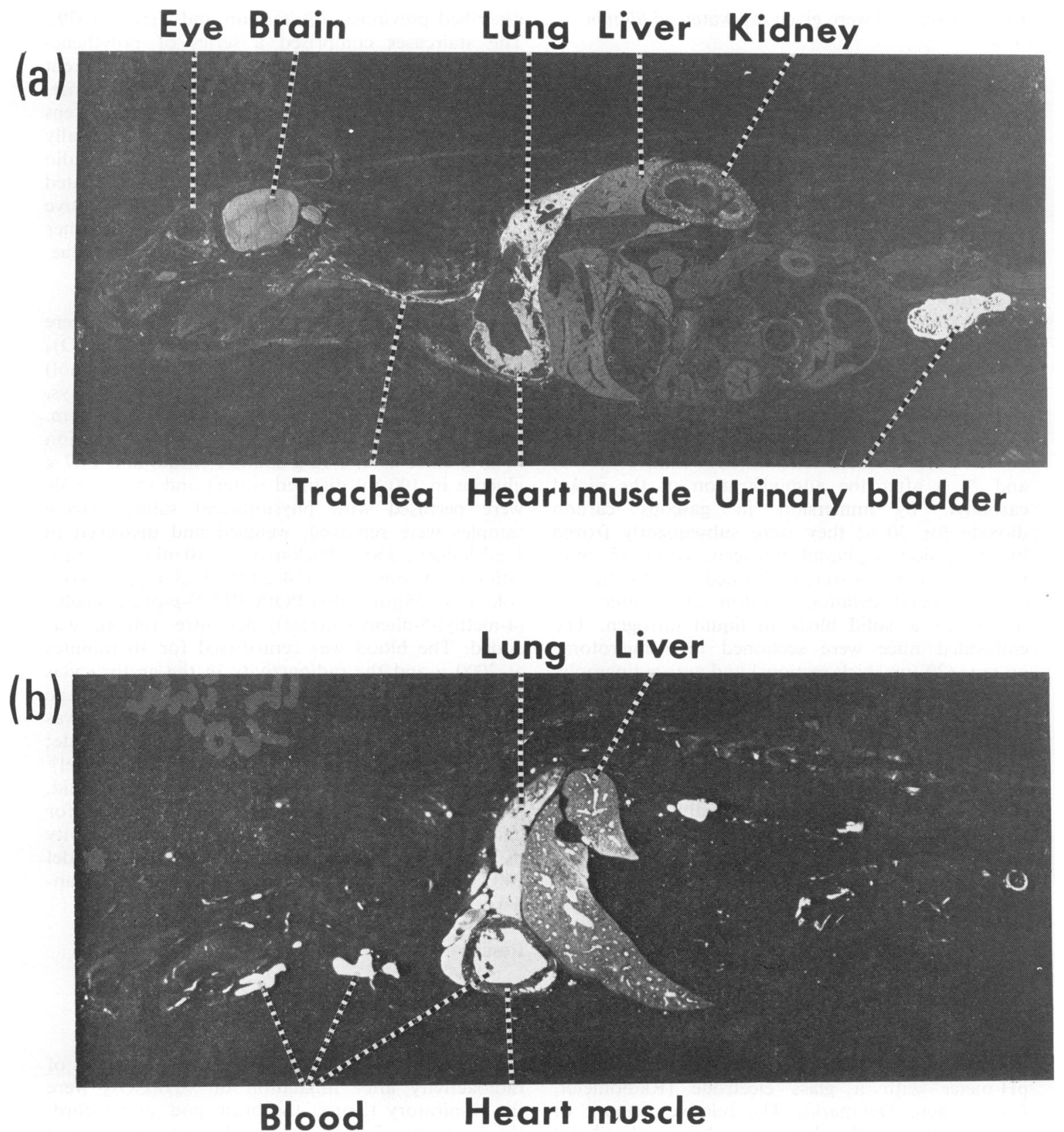

Fig. 1 Autoradiograms of mice $1 \mathrm{~h}$ after inhalation of ${ }^{63} \mathrm{Ni}(\mathrm{CO})_{4}$ (a) and $\left.\mathrm{Ni}^{14} \mathrm{CO}\right)_{4}$ (b). In (a) there is a high level of radioactivity (white areas) in the lung and trachea, the kidney cortex, the urinary bladder, the brain, the heart muscle and the diaphragm. In (b) radioactivity is present in the blood. The labelling in other tissues probably also represents radioactivity in the blood. 

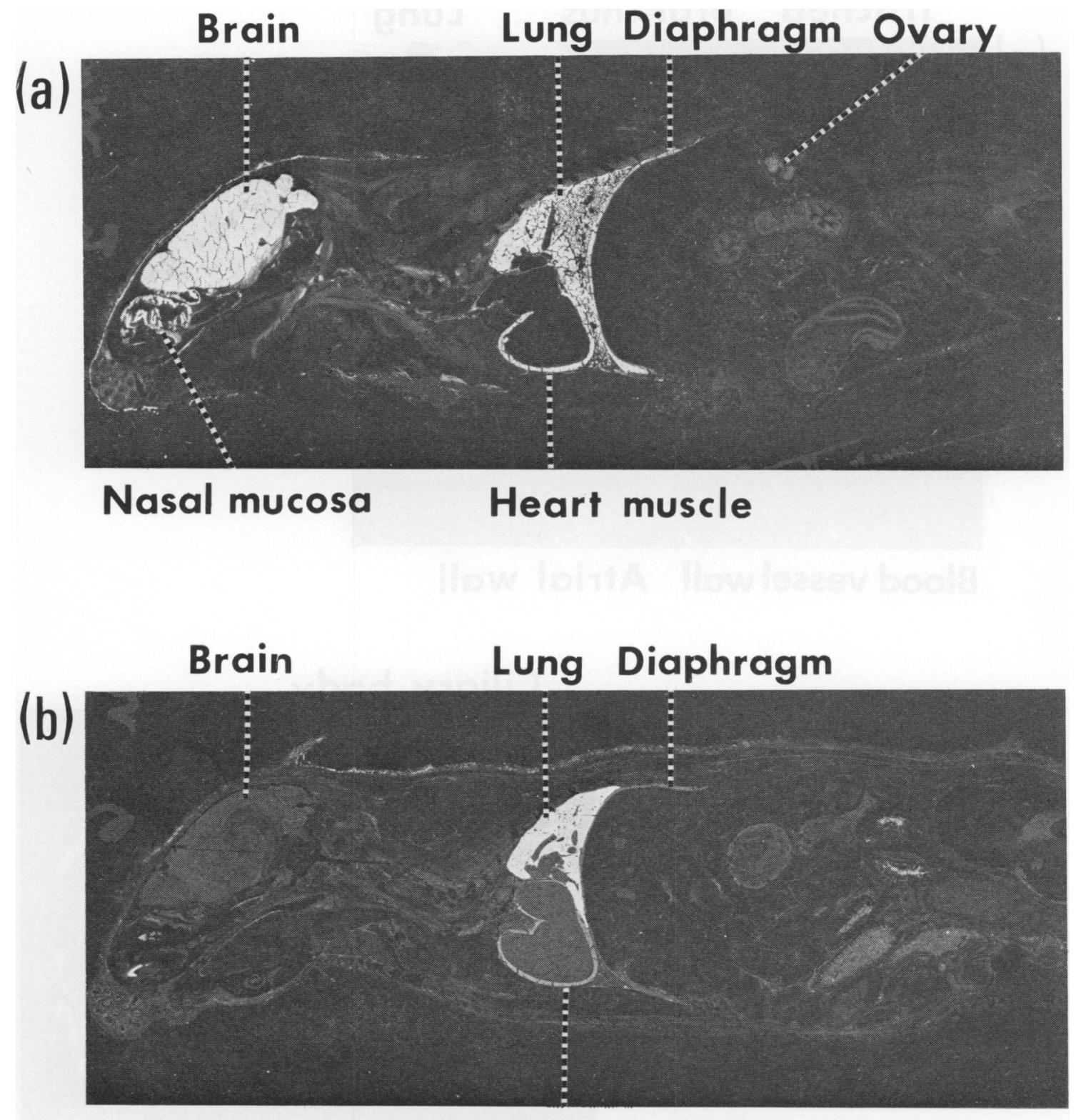

\section{Heart muscle}

Fig. 2 Autoradiograms of mice $24 \mathrm{~h}$ after administration ${ }^{\circ}{ }^{63} \mathrm{Ni}(\mathrm{CO})_{4}$ by inhalation (a) and by intravenous injection (b). After inhalation (a), a high level of radioactivity is present in the lung, the nasal mucosa, the brain, the heart muscle and the diaphragm. Radioactivity is also high in the corpora lutea of the ovary. After intravenous injection (b), the highest amount of radioactivity is present in the lung. The radioactivity in the heart muscle, the diaphragm and the brain is lower than after inhalation. 


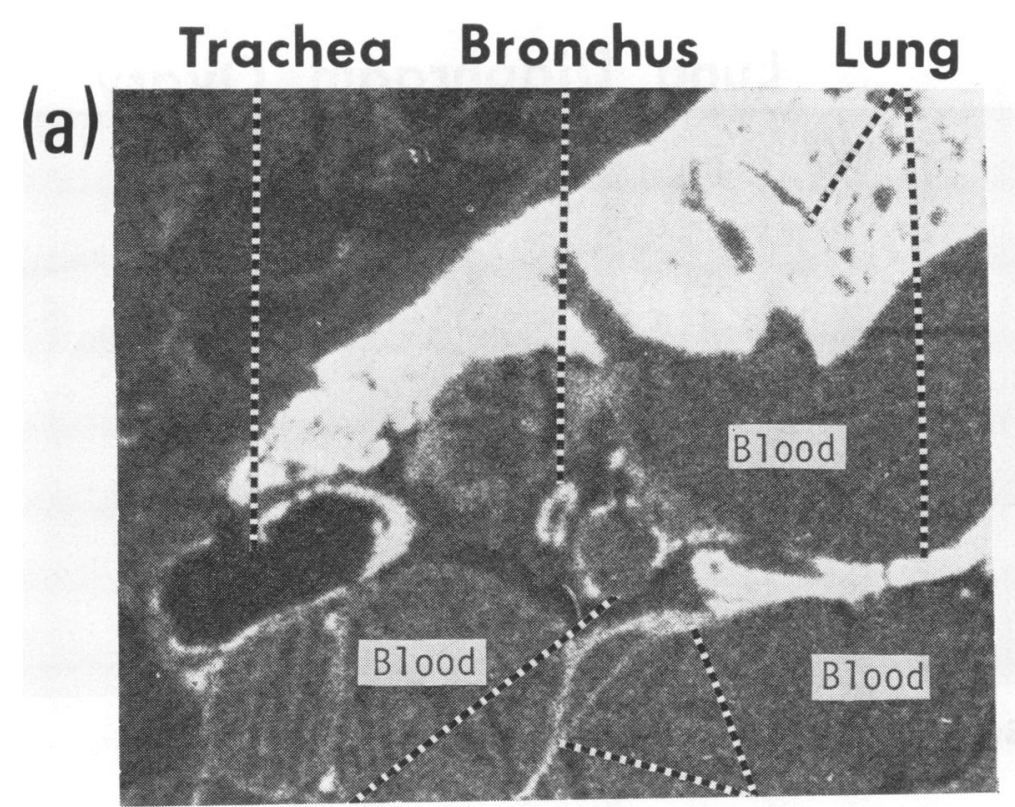

Blood vessel wall Atrial wall

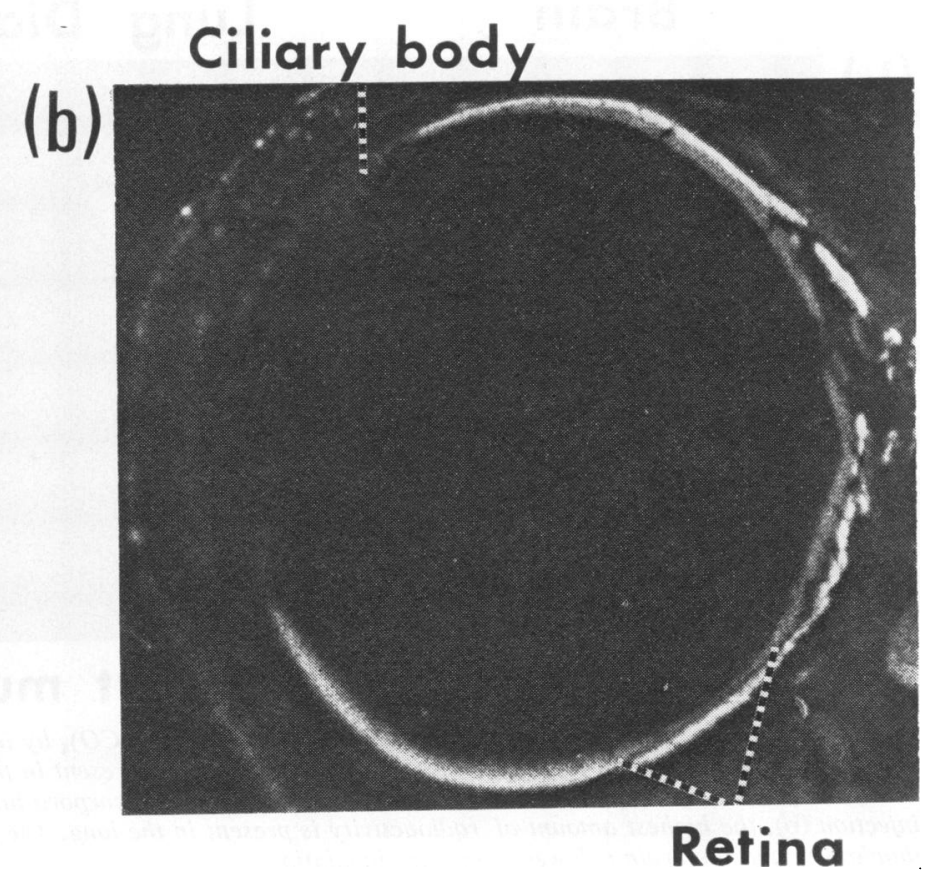



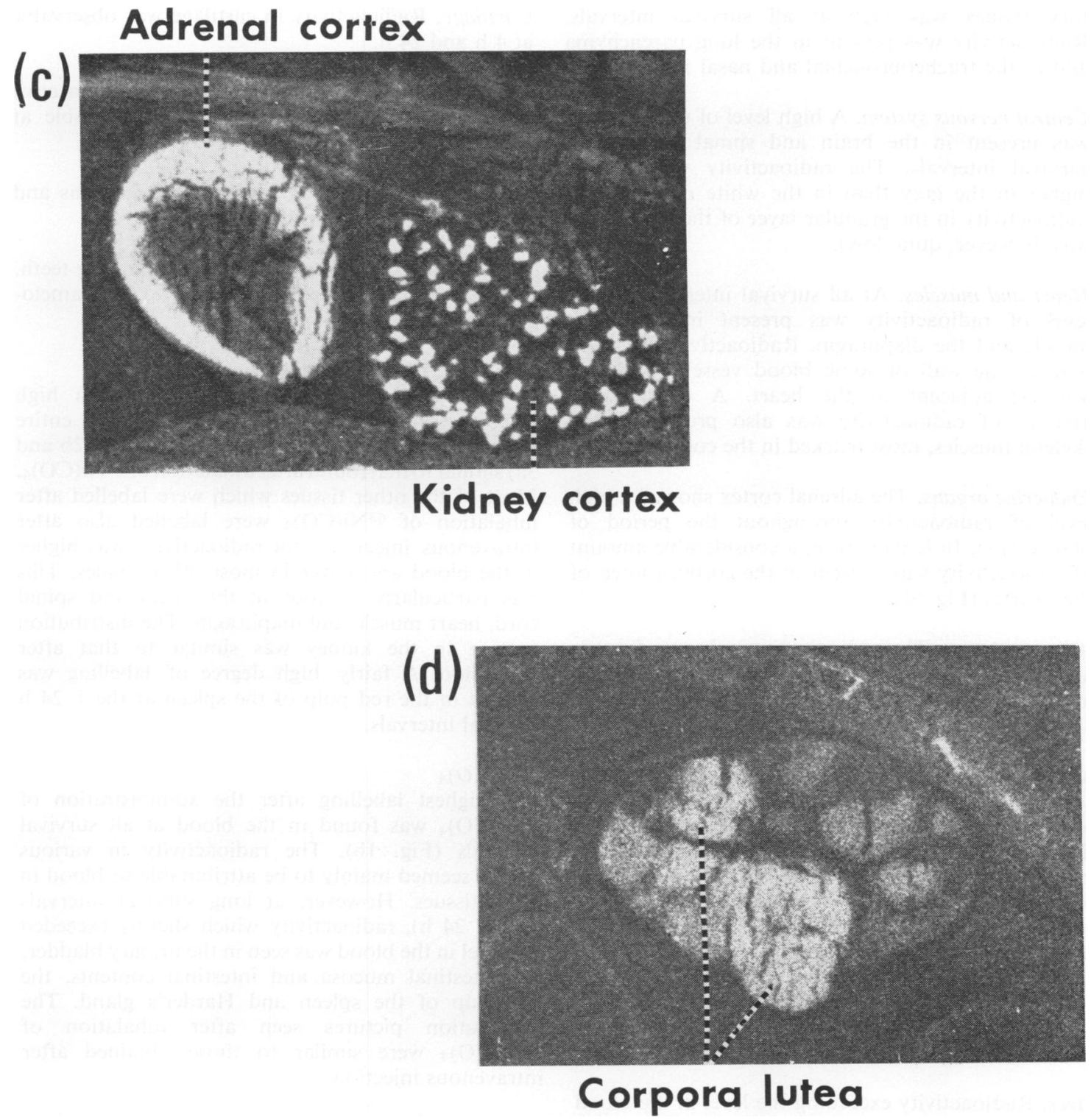

Fig. 3 Details of whole-body autoradiograms of mice after administration of ${ }^{63} \mathrm{Ni}(\mathrm{CO})_{4}$. (a) The lung region dorsal to the heart $4 \mathrm{~h}$ after an intravenous injection. A high level of radioactivity is present in the lung parenchyma, in the tracheal and bronchial mucosa, in the wall of a blood vessel and in the atrial wall. (b) An eye of a pigmented mouse $24 \mathrm{~h}$ after inhalation. Radioactivity is present in the retina most markedly in an area close to the pigment epithelium, probably corresponding to the layer of rods and cones. (c) Adrenal and kidney cortex $4 \mathrm{~h}$ after intravenous injection. Radioactivity is present in the adrenal cortex and in distinct areas of the kidney cortex. (d) Ovary 24 h after inhalation. Radioactivity is present in the corpora lutea. 
inhalation of ${ }^{63} \mathrm{Ni}(\mathrm{CO})_{4}$ was as described below.

Respiratory tissues. The radioactivity in the respiratory tissues was high at all survival intervals. Radioactivity was present in the lung parenchyma and in the tracheobronchial and nasal mucosa.

Central nervous system. A high level of radioactivity was present in the brain and spinal cord at all survival intervals. The radioactivity was slightly higher in the grey than in the white matter. (The radioactivity in the granular layer of the cerebellum was, however, quite low).

Heart and muscles. At all survival intervals, a high level of radioactivity was present in the heart muscle and the diaphragm. Radioactivity was also high in the wall of some blood vessels (probably arteries) adjacent to the heart. A considerable amount of radioactivity was also present in the skeletal muscles, most marked in the costal muscles.

Endocrine organs. The adrenal cortex showed a high level of radioactivity throughout the period of observation. In female mice, a considerable amount of radioactivity was present in the corpora lutea of the ovaries (Fig 3d).

Adipose tissues. The radioactivity in brown fat was high, especially at the short survival intervals. A moderate level of radioactivity was present in the abdominal fat.

Kidney and urinary bladder. A high level of radioactivity was present in the kidney and the urinary bladder, most marked $1 \mathrm{~h}$ and $4 \mathrm{~h}$ after administration (Fig. 1a). In the kidney, the radioactivity was localised in distinct areas of the cortex and the zone between the cortex and the medulla.

Eye. A high level of radioactivity was present in the retina, adjacent to the pigment epithelium, probably corresponding to the layer consisting of rods and cones (Fig. 3b). The radioactivity in the melanin was low.

Liver. Radioactivity exceeding the level in the blood was present at $5 \mathrm{~min}$ and $1 \mathrm{~h}$, but decreased to a low level at longer survival intervals (Figs 1a and 2a).

Digestive tract. A considerable degree of radioactivity was present in the squamous epithelium of the forestomach at the 1-24 h survival intervals. Radioactivity at a rather low level was also present in other parts of the gastrointestinal mucosa at all survival intervals. A low level of radioactivity was observed in the intestinal contents at long survival intervals.

Cartilage. Radioactivity in cartilage was observable at $4 \mathrm{~h}$ and $24 \mathrm{~h}$.

Connective tissues. Labelling of the connective tissues of viscera and muscles was observable at $4 \mathrm{~h}$ and $24 \mathrm{~h}$.

Skin. Low labelling was present in the dermis and epidermis at most survival intervals.

Teeth. A high uptake was seen in developing teeth, with a localisation corresponding to the ameloblastic layer.

\section{${ }^{63} \mathrm{Ni}(\mathrm{CO})_{4}$ intravenous injection}

After intravenous injection of ${ }^{63} \mathrm{Ni}(\mathrm{CO})_{4}$, a high level of radioactivity was present in the entire respiratory tract at all survival intervals (Fig. $2 b$ and 3a) similar to that found after inhalation of ${ }^{63} \mathrm{Ni}(\mathrm{CO})_{4}$. Most of the other tissues which were labelled after inhalation of ${ }^{63} \mathrm{Ni}(\mathrm{CO})_{4}$ were labelled also after intravenous injection, but radioactivity was higher in the blood and lower in most other tissues. This was particularly obvious in the brain and spinal cord, heart muscle and diaphragm. The distribution pattern in the kidney was similar to that after inhalation. A fairly high degree of labelling was present in the red pulp of the spleen at the 1-24 h survival intervals.

$\mathrm{Ni}\left({ }^{14} \mathrm{CO}\right)_{4}$

The highest labelling after the administration of $\mathrm{Ni}\left({ }^{14} \mathrm{CO}\right)_{4}$ was found in the blood at all survival intervals (Fig. 1b). The radioactivity in various tissues seemed mainly to be attributable to blood in these tissues. However, at long survival intervals (4 and $24 \mathrm{~h}$ ), radioactivity which slightly exceeded the level in the blood was seen in the urinary bladder, the intestinal mucosa and intestinal contents, the red pulp of the spleen and Harder's gland. The distribution pictures seen after inhalation of $\mathrm{Ni}\left({ }^{14} \mathrm{CO}\right)_{4}$ were similar to those obtained after intravenous injection.

The ability of cations to displace ${ }^{63} \mathrm{Ni}$ from the tissues The cations in the incubation solutions were able to displace the ${ }^{63} \mathrm{Ni}$ from the tissues studied, namely the lung, the brain, the heart muscle and the blood (Table 1). The ability of the cations to displace the ${ }^{63} \mathrm{Ni}$ increased with increasing valence and $\mathrm{H}^{+}$was also effective. After the incubations in $\mathrm{La}^{+++}$, no radioactivity could be detected in the tissues with the method used. Small variations in the $\mathrm{pH}$ values 
Table 1 The ability of cations to displace ${ }^{63} \mathrm{Ni}$ from the lung, the brain, the heart muscle and the blood*

\begin{tabular}{|c|c|c|c|c|c|c|}
\hline \multirow[t]{2}{*}{ Cation } & \multirow{2}{*}{$\begin{array}{l}\text { Conc. } \\
(M)\end{array}$} & \multirow{2}{*}{$\begin{array}{l}\text { pH of incubation } \\
\text { solution }\end{array}$} & \multicolumn{4}{|c|}{ Per cent ${ }^{\mathrm{s}} \mathrm{Ni}$ bound after incubation } \\
\hline & & & Lung & Brain & Heart muscle & Blood \\
\hline$-\left(\mathrm{H}_{2} \mathrm{O}\right)$ & - & $6 \cdot 2$ & $100 \pm 11$ & $100 \pm 4$ & $100 \pm 17$ & $100 \pm 10$ \\
\hline $\mathrm{Na}^{+}$ & $0 \cdot 1$ & $6 \cdot 0$ & $74 \pm 6$ & $78 \pm 5$ & $63 \pm 8$ & $78 \pm 8$ \\
\hline $\mathbf{K}^{+}$ & 0.1 & $5 \cdot 7$ & $55 \pm 8$ & $72 \pm 6$ & $67 \pm 9$ & $89 \pm 7$ \\
\hline $\mathrm{Ba}^{++}$ & $0 \cdot 1$ & $5 \cdot 7$ & $23 \pm 5$ & $31 \pm 7$ & $33 \pm 9$ & $44 \pm 4$ \\
\hline $\mathbf{M g}^{++}$ & $0 \cdot 1$ & $5 \cdot 4$ & $23 \pm 7$ & $25 \pm 4$ & $19 \pm 4$ & $11 \pm 7$ \\
\hline $\mathrm{La}^{+++}$ & $0 \cdot 1$ & $5 \cdot 0$ & 0 & 0 & 0 & 0 \\
\hline $\mathbf{H}^{+}$ & 0.001 & $3 \cdot 0$ & $8 \pm 2$ & $6 \pm 2$ & $4 \pm 3$ & 0 \\
\hline
\end{tabular}

*Tissue sections of a mouse killed $5 \mathrm{~min}$ after inhalation of ${ }^{63} \mathrm{Ni}(\mathrm{CO})$, were freeze-dried and then incubated in distilled water or in different cation-chloride solutions. After subsequent autoradiography, a relative densitometric analysis of the autoradiograms with respect to the ${ }^{3} \mathrm{Ni}$ radioactivity in the lung, the brain, the heart muscle and the blood was performed. The mean value of the radioactivity in the tissues of the sections incubated in distilled water is assigned the value $100 \%$ and the radioactivities of the tissues of the cation chloride-incubated sections are expressed as percentages of this value (mean $\pm \mathrm{SD} ; \mathrm{n}=5$ ).

Table 2 Tissue radioactivity after intravenous injection of $1 \mu \mathrm{Ci}{ }^{63} \mathrm{Ni}(\mathrm{CO})_{4}(0.90 \mathrm{mg} / \mathrm{kg})$ in mice. Three mice were used at $24 \mathrm{~h}$ and 4 days and two* at $1 \mathrm{~h}$. The results show the mean dpm/100 mg tissue with the range, and the mean of the total dpm in the tissue

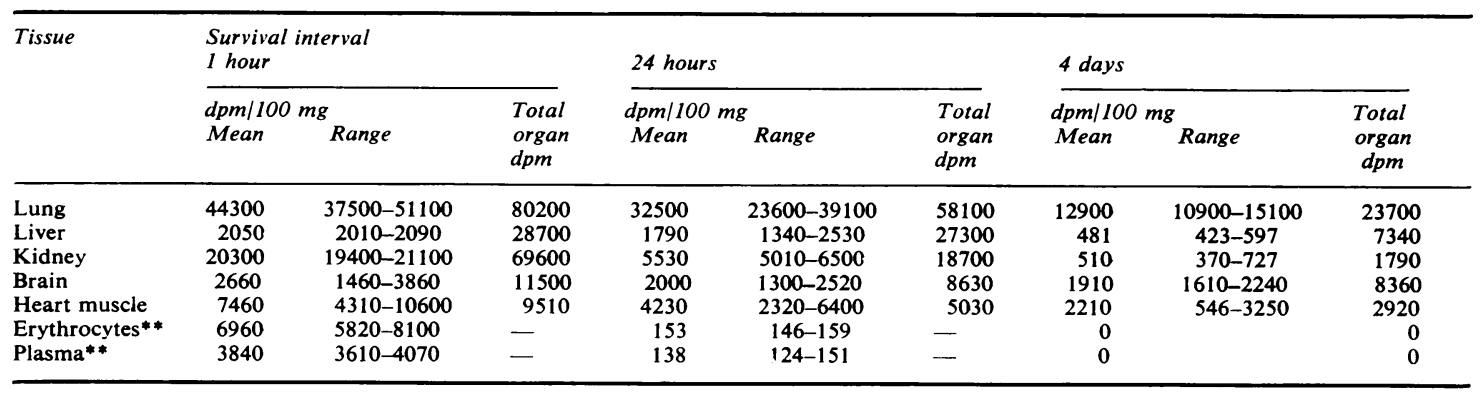

* One of three injected mice died.

**Results expressed as $\mathrm{dpm} / 100 \mu \mathrm{l}$ whole blood.

were found in the cation-chloride solutions. It was obvious that these small variations had no relation to the displacement of the ${ }^{63} \mathrm{Ni}$ from the tissues.

\section{LIQUID SCINTILLATION COUNTING}

When the radioactivity in the tissues of mice injected intravenously with ${ }^{63} \mathrm{Ni}(\mathrm{CO})_{4}$ was quantified by liquid scintillation counting, the high radioactivity in the lung compared with other tissues was obvious at all survival intervals (Table 2). The radioactivity in the brain was fairly constant over the observational period. In the blood at the $1 \mathrm{~h}$ survival interval more radioactivity was present in the erythrocytes than in the plasma. The amounts of nickel incorporated into the various organs represent only small percentages of the administered dose. Thus, in the lung $3.6 \%$ of the dose was present at $1 \mathrm{~h}$ and $1 \cdot 1 \%$ was retained 4 days after injection.

\section{Discussion}

The autoradiographs obtained after the administration of ${ }^{63} \mathrm{Ni}(\mathrm{CO})_{4}$ were totally different from those obtained after the administration of $\mathrm{Ni}\left({ }^{14} \mathrm{CO}\right)_{4}$, which shows that nickel carbonyl is decomposed in vivo. Attempts to localise the non-metabolised nickel carbonyl in the tissues, by low-temperature autoradiography, were unsuccessful, probably because of the high volatility of the substance. The radioactivity in the animals given $\mathrm{Ni}\left({ }^{14} \mathrm{CO}\right)_{4}$ was confined mainly to the blood. The formation of ${ }^{14}$ CO-haemoglobin, shown by Kasprzak and Sunderman (1969), probably accounts for most of this labelling. The most prominent feature after the administration of ${ }^{63} \mathrm{Ni}(\mathrm{CO})_{4}$ was the high labelling of the lung, which is in agreement with the results obtained by previous authors (Armit, 1908; Barnes and Denz, 1951; Sunderman and Selin, 1968). Other tissues which accumulated a large amount of ${ }^{63} \mathrm{Ni}$ were the brain and spinal cord, the heart muscle, the diaphragm, brown fat, the adrenal cortex and the corpora lutea of the ovaries.

The ${ }^{63} \mathrm{Ni}$ in the lung as well as in the brain, the heart and the blood was displaced by incubation of tissue sections in solutions containing different cations. The effectiveness increased with increasing valence and $\mathrm{H}^{+}$was also effective. These observations suggest that, during the incubation, nickel is displaced from the tissues by an ion exchange process. Characteristics of this process are an increasing 
affinity to the anionic groups as the valence of the cations increases, and, provided that the anionic groups have the character of weak acids, a strong affinity for $\mathrm{H}^{+}$(Kunin, 1958). This correlates well with observations made in the present study and implies that nickel probably is bound to the tissues in the divalent state $\left(\mathrm{Ni}^{++}\right)$. The binding sites may be negatively charged groups in macromolecules such as carboxyl, hydroxyl and sulphydryl groups in proteins and phosphate groups in nucleic acids. The incubations were carried out with tissue sections of a mouse killed 5 min after inhalation of ${ }^{63} \mathrm{Ni}(\mathrm{CO})_{4}$. Under the experimental conditions used, no radioactivity could be detected in the tissues after the displacement of the ${ }^{63} \mathrm{Ni}$ with $\mathrm{La}^{+++}$, which indicates that the predominating fraction of non-volatile nickel is present in the ionic state already at this short survival interval. This raises the question of which factors may determine the distribution and breakdown of nickel carbonyl in the tissues.

Unchanged nickel carbonyl has been identified in the blood and breath several hours after administration (Sunderman and Selin, 1968; Sunderman et al., 1968), which indicates that the breakdown of nickel carbonyl in the tissues can take place during a fairly long period. Nickel carbonyl is soluble in lipids and the unchanged substance should easily be able to pass various biological membranes. If the lipid solubility of the substance were the major factor determining the localisation of nickel in the tissues, distribution pictures similar to those obtained after the administration of other lipid-soluble substances would be expected. DDT, dieldrin and dimethylmercury are examples of substances with high lipid solubility, the distribution of which has been studied by whole-body autoradiography (Bäckström et al., 1965; Östlund, 1969). These substances showed a marked accumulation in all depots of body fat. Brown fat was highly labelled after the administration of ${ }^{63} \mathrm{Ni}(\mathrm{CO})_{4}$, while other adipose tissues, such as the abdominal fat, were only moderately labelled. Tissues such as the lung, the brain and spinal cord, the heart and the diaphragm, which were highly labelled after the administration of ${ }^{63} \mathrm{Ni}(\mathrm{CO})_{4}$, were only moderately labelled after the administration of DDT, dieldrin and dimethylmercury. These data do not exclude the possibility that the lipid content of tissues may have some influence on the relative tissue disposition of nickel after the administration of nickel carbonyl, but it is obviously not of major importance. Other factors which may influence the relative tissue distribution of nickel are vascularisation, circulation time and blood content. It is also possible that the distribution of nickel in tissues after the administration of nickel carbonyl may to a large extent be determined by the ability of the tissues to oxidise $\mathrm{Ni}^{0}$ in nickel carbonyl to $\mathrm{Ni}^{++}$. The observation that ionic nickel was the predominant form of the metal detected in the tissues at 5 minutes' survival supports this theory. There is an interesting concordance between the tissue localisation of nickel after the administration of $\mathrm{Ni}(\mathrm{CO})_{4}$ and that of mercury after the administration of metallic mercury. Thus, after the administration of metallic mercury, a high concentration occurs in the brain and spinal cord, the heart and the lung (Berlin et al., 1966; Magos, 1967; Magos et al., 1973). After administration, metallic mercury seems to exist for a short period in the elemental form in the tissues. A large part is exhaled as unchanged $\mathbf{H g}^{\mathbf{0}}$, while the rest is rapidly oxidised to $\mathrm{Hg}^{++}$which becomes bound to the tissues (Magos et al., 1973; Clarkson, 1977). The enzyme system(s) involved in the oxidation of $\mathrm{Hg}^{0}$ have not been established. It has, however, been shown that ethanol inhibits the oxidation of $\mathrm{Hg}^{0}$ in blood (Nielsen-Kudsk, 1969) and probably also in other tissues (Magos et al., 1973). The administration of ethanol will increase the exhalation of $\mathbf{H g}^{\mathbf{0}}$ and diminish the mercury content in tissues such as the brain, the heart and the lungs (Magos et al., 1973). Thus, the ability of the tissues to oxidise $\mathbf{H g}^{\mathbf{0}}$ may have an influence on the tissue concentration of the resulting $\mathrm{Hg}^{++}$. Our study has shown that a much lower concentration of nickel was present in the brain and spinal cord, the heart and the diaphragm after intravenous injection of nickel carbonyl, than after inhalation. The intravenously administered nickel carbonyl was, for technical reasons, administered in $25 \mu \mathrm{l}$ ethanol. It is possible that, by analogy with $\mathbf{H g}^{0}$ (Magos et al., 1973), the ethanol may inhibit the oxidation of the nickel carbonyl, resulting in a diminished tissue concentration. On the other hand, Sunderman and Selin (1968) noted differences between the tissue distribution of inhaled and intravenously injected nickel carbonyl administered without ethanol, indicating that the observed differences in distribution may be due to other factors.

The lung, the central nervous system and the adrenals are target tissues for the toxic effects of nickel carbonyl and these tissues were also found to be highly labelled after the administration of ${ }^{63} \mathrm{Ni}(\mathrm{CO})_{4}$ in the present study. A high labelling was present in the heart muscle. Effects on the heart, reflected in the ECG, have been observed following human exposure to nickel carbonyl (Eisler and Rosmanith, 1960). These data indicate that the selective toxicity of nickel carbonyl probably is correlated with the distribution of the nickel. Radioactivity was present in the kidney with a distribution similar to that observed after the 
administration of ${ }^{63} \mathrm{NiCl}_{2}$ (Oskarsson and Tjälve, 1979). Radioactivity could also be detected in connective tissues and cartilage and in the squamous epithelium of the forestomach, tissues which are labelled after the administration of ${ }^{63} \mathrm{NiCl}_{2}$ (Oskarsson and Tjälve, 1979). Thus, the labelling of these tissues probably reflects the distribution of ${ }^{63} \mathrm{Ni}^{++}$ which gradually has been released from various tissues and eventually will be excreted in the urine. The liquid scintillation measurements showed that the loss of nickel from the brain was slower than that from the other tissues studied. A retention of ${ }^{63} \mathrm{Ni}^{++}$in the central nervous system at long intervals has been observed after the administration of ${ }^{63} \mathrm{NiCl}_{2}$ (Oskarsson and Tjälve, 1979). Magos (1967) showed that the mercury present in the brain after administration of $\mathbf{H g}^{\mathbf{0}}$ is released more slowly than the mercury in other tissues.

This work was supported by the Swedish Work Environment Fund (No. 74/87).

\section{References}

Armit, H. W. (1907). The toxicology of nickel carbonyl. Part I. Journal of Hygiene, 7, 525-551.

Armit, H. W. (1908). The toxicology of nickel carbonyl. Part II. Journal of Hygiene, 8, 565-600.

Bäckström, J., Hansson, E., and Ullberg, S. (1965). Distribution of $\mathrm{C}^{14}$-DDT and $\mathrm{C}^{14}$-dieldrin in pregnant mice determined by whole-body autoradiography. Toxicology and Applied Pharmacology, 7, 90-96.

Barnes, J. M., and Denz, F. A. (1951). The effect of 2-3 dimercapto-propanol (BAL) on experimental nickel carbonyl poisoning. British Journal of Industrial Medicine, 8, 117-126.

Berlin, M., and Ullberg, S. (1963). Accumulation and retention of mercury in the mouse. I. An autoradiographic study after a single intravenous injection of mercuric chloride. Archives of Environmental Health, 6, 589-601.

Berlin, M., Jerksell, L. G., and von Ubisch, H. (1966). Uptake and retention of mercury in the mouse brain. Archives of Environmental Health, 12, 33-42.

Clarkson, T. W. (1977). Mercury poisoning. In Clinical Chemistry and Chemical Toxicology of Metals, pp. 189-200.
Edited by S. S. Brown. Elsevier: North-Holland.

Eisler, L., and Rosmanith, J. (1960). Tetracarbonylnickel intoxication by inhalation. Pracovni Lékaŕství, 12, 84-86.

Hackett, R. L., and Sunderman, F. W., Jr. (1967). Acute pathological reactions to administration of nickel carbonyl. Archives of Environmental Health, 14, 604-613.

International Agency for Research on Cancer (1976). Monographs on the Evaluation of Carcinogenic Risk of Chemicals to Man, Volume 11. IARC: Lyon.

Kasprzak, K. S., and Sunderman, F. W., Jr. (1969). The metabolism of nickel carbonyl- ${ }^{14} \mathrm{C}$. Toxicology and Applied Pharmacology, 15, 295-303.

Kincaid, J. F., Strong, J. S., and Sunderman, F. W. (1953) Nickel poisoning. I Experimental study of the effects of acute and subacute exposure to nickel carbonyl. Archives of Industrial Hygiene and Occupational Medicine, 8, 48-60.

Kunin, R. (1958). In Ion Exchange Resins, Second edition, pp. 5-54. John Wiley \& Sons: New York.

Magos, L. (1967). Mercury-blood interaction and mercury uptake by the brain after vapor exposure. Environmental Research, 1, 323-337.

Magos, L., Clarkson, T. W., and Greenwood, M. R. (1973). The depression of pulmonary retention of mercury vapor by ethanol: identification of the site of action. Toxicology and Applied Pharmacology, 26, 180-183.

Nielsen-Kudsk, F. (1969). Factors influencing the in vitro uptake of mercury vapour in blood. Acta Pharmacologica et Toxicologica, 27, 161-172.

Oskarsson, A., and Tjälve, H. (1979). An autoradiographic study on the distribution of ${ }^{63} \mathrm{NiCl}_{2}$ in mice. Annals of Clinical and Laboratory Science, 9, 47-59.

Östlund, K. (1969). Studies on the metabolism of methyl mercury and dimethyl mercury in mice. Acta Pharmacologica et Toxicologica, 27, Suppl. 1, 1-132.

Sunderman, F. W., Jr., and Selin, C. E. (1968). The metabolism of nickel-63 carbonyl. Toxicology and Applied Pharmacology, 12, 207-218.

Sunderman, F. W., Jr., Roszel, N. O., and Clark, R. J. (1968). Gas chromatography of nickel. Archives of Environmental Health, 16, 836-843.

Ullberg, S. (1954). Studies on the distribution and fate of $\mathbf{S}^{35}$-labelled benzylpenicillin in the body Acta Radiologica, Suppl. 118, 1-110.

Von Ludewigs, H.-J., and Theiss, A. M. (1970). Arbeitsmedizinische Erkenntnisse bei der Nickelcarbonylvergiftung. Zentralblatt für Arbeitsmedizin und Arbeitsschutz, 20, 329-339.

Vuopala, U., Huhti, E., Takkunen, J., and Huikko, M. (1970). Nickel carbonyl poisoning. Report of 25 cases. Annals of Clinical Research, 2, 214-222. 